\title{
EFFECT OF NEONATAL EXPOSURE OF MONOSODIUM OLUTAMATE IN KIDNEY OF ALBINO MICE - A HISTOLOGICAL STUDY
}

\author{
Bhattacharya $T^{1}$, Ghosh $S K^{2}$
}

${ }^{1}$ Deptartment of Anatomy, Medical College Kolkata, India, ${ }^{2}$ Department of Anatomy, Nepal Medical College Teaching Hospital, Kathmandu, Nepal

\begin{abstract}
Monosodium Glutamate (MSG) is a commonly used food additive. Scientists have found that MSG has toxic effects in several tissues and organs like neurons, liver, testes, ovary, kidneys etc due to oxidative stress both after exposure in neonatal period as well as in adult animal models. Although various reports have suggested that MSG has damaging effect in kidneys only few histological studies are available. This study was done to observe any histological changes in kidneys of albino mice after neonatal exposure with MSG. Study showed significant changes in weight and volume of kidneys in gross morphology. Increased urinary space and dilatation of proximal convoluted tubules (PCT) and distal convoluted tubules (DCT) were constant finding in experimental animals. There were loss of luminal microvilli and reduced height of lining cells of both PCT and DCT.
\end{abstract}

\section{KEYWORDS}

Monosodium Glutamate (MSG), proximal convoluted tubules (PCT), distal convoluted tubules (DCT), glomerulus

\section{CORRESPONDING AUTHOR}

Dr. Tapati Bhattacharya,

Associate Professor,

Department of Anatomy, Medical College Kolkata

88 College Street, India, Pin: 700073,

Email : dk11.das@gmail.com 


\section{INTRODUCTION}

Monosodium Glutamate (MSG) is a commonly used food additive since ancient time. Its taste sensation is called savoury ${ }^{1}$ MSG is an essential amino acid present in many of our food and food products. It acts on glutamate receptors and act as neurotransmitters in neurones of CNS. ${ }^{2}$ Solomon $^{3}$ has mentioned that MSG in lowest dose of 0.3-1 gm per day in human has toxic effects. Animal studies demonstrated neonatal MSG consumption caused obesity along with Insulin resistance and reduced glucose tolerance in later life of rodents. ${ }^{4}$ In a placebo control study using MSG dose ranging from 57 - 150 $\mathrm{mg} / \mathrm{kg}$ was resulted in muscle pain and change in mechanical sensitivity in human. ${ }^{5}$ Scientists have reported high dose of MSG 75 gms per kg in human elevates systolic blood pressure. ${ }^{6}$ Both animal model and human studies have shown that use of MSG had toxic effects on reproductive system. It causes distinguishable necrotic changes in the endometrial and myometiral layers of uterus. ${ }^{7}$ Administration of MSG at a dose of $2 \mathrm{mg} / \mathrm{gm}$ of body weight during various perinatal period of life leads to reduction in sperm count, reduced serum testosterone level in addition to atrophied seminiferous tubules in adult male rats compared to control animals. ${ }^{8}$ Scientist claimed that the degenerative process is due to enhanced oxidative stress and increased lipid peroxidation in cell. ${ }^{8}$ MSG induces kidney damage from oxidative stress and decrease elimination of free radicals in cells. ${ }^{?}$

The association between dietary factors including MSG and risk of kidney disease has been hypothecated in human studies. Kidneys are highly sensitive to ischaemic and other toxic chemicals. ${ }^{9}$ Though many adverse effcets on different organs including kidneys had been reported, histological observations are scarce.

Purpose of this study is to see histological changes if any in kidneys after neonatal exposure of MSG in albino mice, sacrificing on $75^{\text {th }}$ day. The observations were compared with that of findings in control animals. The study period spanned approximately for one year from 2007 to 2008. Ethical approval was obtained from Institutional review committee.

\section{MATERIALS AND METHODS}

It is an experimental study conducted in Mahatama Gandhi Institute of Medical Sciences (MGIMS). The study period spaned approximately for one year from 2007 to 2008. This study was undertaken to see histological changes if any in kidney after neonatal exposure of MSG in albino mice sacrificing on $75^{\text {th }}$ day. The observations were compared with findings in control animals. Preparation of MSG solution for injection: 4 gram MSG crystals were dissolved in 100 $\mathrm{ml}$ of distilled water. Thus $0.05 \mathrm{ml}$ solution contained $2 \mathrm{mg}$ of MSG and the strength of the solution was $4 \%$. Fresh preparations were used after filtration just before subcutaneous injection for every batch of mice. Distilled water was used in control animal.

Twenty Five albino mice pups bred in MGIMS, India were given subcutaneous injection of MSG solution at a dose of $2 \mathrm{mg}$ per gram of body weight on $3^{\text {rd }}, 5^{\text {th }}, 7^{\text {th }}$ $9^{\text {th }}$ and $11^{\text {th }}$ day postnatal. ${ }^{10,11}$ The dose was calculated for individual pups according to their weight each time. Similiarly 25 pups were taken as control and injected with distilled water. The volume of distilled water was calculated as per weight of pup like that of experimental animals. The pups were sacrificed on $75^{\text {th }}$ day postnatal by injecting Thiopentone $\mathrm{Na}$ in a dose of $0.005 \mathrm{mg} / \mathrm{gm}$ of body weight intraperitoneally after proper dilution with distilled water. ${ }^{12}$ Abdominal cavity was opened wih incision on whole pup and then the pups were subsequently immersed in $10 \%$ formalin sol ${ }^{\mathrm{n}}$. After $48 \mathrm{hrs}$. kidneys were dissected and weight and volume (by water disperson method) of each kidney was recorded and subsequently processed for paraffin embedding and sectioning (5 micron thick). Sections were stained with Haemotoxylin and Eosin, Masson's Trichrome stain and finally examined under light microscope.

\section{RESULTS}

\section{General Observation:}

Initially the food intake by experimental animals increased resulting in gain in weight (Fig 4) but later on the animals were drowsy and showed less interest in food and by $75^{\text {th }}$ day both control and experimental group showed similar weight (Fig. 5). It was observed that volume and weight of kidney in experimental group were less compare to that of control group (Fig. 6 \& 7). When the animals were sacrificed on $75^{\text {th }}$ day, mean volume of kidneys were $0.17 \mathrm{ml}$. in control group whereas that of experimental group was $0.158 \mathrm{ml}$. Mean weight of kidneys in control group was $171.62 \mathrm{mg}$ where as in exeprimental group it was $148.60 \mathrm{mg}$ (Table 1 \& 2).

\section{Histological Observation:}

\section{Control Animal:}

Both $\mathrm{H}$ and $\mathrm{E}$ and Masson's trichrome stained section of kidney of control animal showed normal histological features. Cortical part of kidney showed renal corpuscles, proximal and distal convoluted tubules. Parietal wall of renal corpuscles were lined by simple squamous eptithelium. Podocytes were not seen clearly. Both vascular pole and macula densa adjoining DCT could be seen lined by tall cuboidal cells with irregular margin possibly due to presence of microvilli; the lumen of different tubules of PCT were very narrow lined by tall cells (Fig 1).

\section{Experimental animal:}

The histological features of the experimental group of animals showed some degenerative changes in renal cortex. Renal corpuscles were larger with increased urinary glomerutar space. At vascular pole macula densa could be seen (Fig 2). Many PCT \& DCT showed dilatation and lining cells were smaller when compared with that of control. The tubules were separated from each other due to oedema in the interstitial space (Fig 3). No fibrosis was seen. Glomeruler cells were few and some vacuoles were 
Table 1: Volume and weight of kidney of Control animal.

\begin{tabular}{|cccccc|}
$\begin{array}{c}\text { Maximum } \\
\text { volume of } \\
\text { kidney in ml. }\end{array}$ & $\begin{array}{c}\text { Minimum } \\
\text { volume of } \\
\text { kidney in ml. }\end{array}$ & $\begin{array}{c}\text { Mean } \\
\text { volume of } \\
\text { kidney in } \\
\text { ml. }\end{array}$ & $\begin{array}{c}\text { Maximum } \\
\text { weight of } \\
\text { kidney in } \mathbf{m g} .\end{array}$ & $\begin{array}{c}\text { Minimum } \\
\text { weight of } \\
\text { kidney in } \mathbf{~ m g} .\end{array}$ & $\begin{array}{c}\text { Mean weight } \\
\text { of kidney in } \\
\text { mg. }\end{array}$ \\
0.2 & 0.16 & 0.17 & 220 & 153 & 171.62 \\
\hline
\end{tabular}

\begin{tabular}{|cccccc|}
\hline \multicolumn{7}{|c|}{ Table 2: Volume and weight of kidney of Experimental animal. } \\
$\begin{array}{c}\text { Maximum } \\
\text { volume of } \\
\text { kidney in ml. }\end{array}$ & $\begin{array}{c}\text { Minimum } \\
\text { volume of } \\
\text { kidney in } \mathbf{m l} .\end{array}$ & $\begin{array}{c}\text { Mean volume } \\
\text { of kidney in } \\
\text { ml. }\end{array}$ & $\begin{array}{c}\text { Maximum } \\
\text { weight of } \\
\text { kidney in } \mathbf{m g} .\end{array}$ & $\begin{array}{c}\text { Minimum } \\
\text { weight of } \\
\text { kidney in } \mathbf{~ m g . ~}\end{array}$ & $\begin{array}{c}\text { Mean weight } \\
\text { of kidney in } \\
\text { mg. }\end{array}$ \\
0.19 & 0.11 & 0.158 & 200 & 121 & 148.60 \\
\hline
\end{tabular}

seen in it. Masson's trichrome stained section showed less connective tissue in interstitial spaces compared to that of kidney of control animals (Fig. 3).

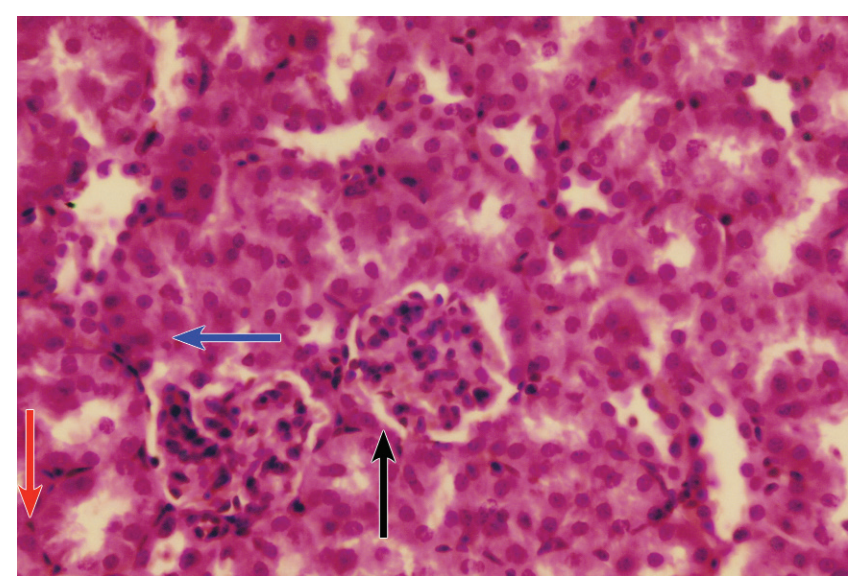

Fig. 1: Microphotograph of a section of kidney of control animal showing (glomeruli on black arrow, PCT blue arrow and DCT red arrow) PCT were lined by tall cuboidal cells resulting in narrow lumen $(\mathrm{H} / \mathrm{E}$ $\mathrm{X} 400$ )

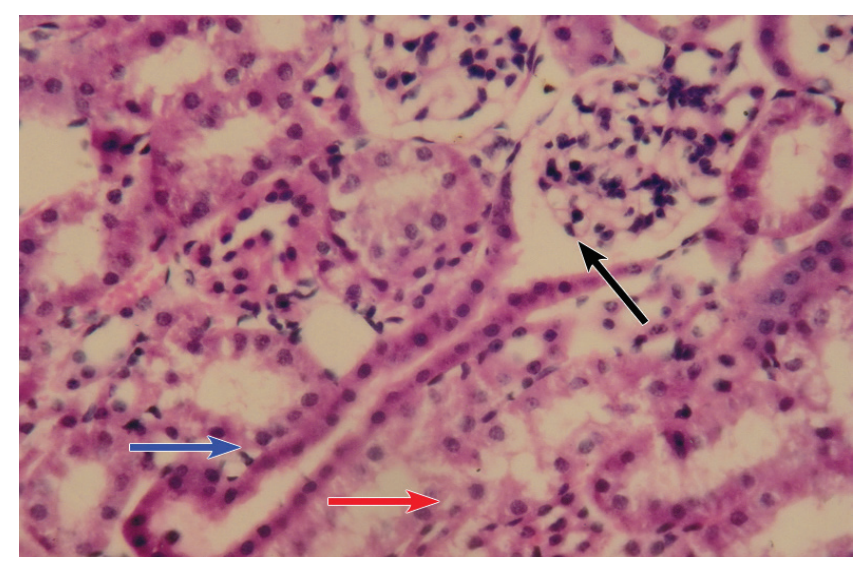

Fig. 2: Microphotograph of a section of kidney of experimental animal showing enlarged renal corpuscles (black arrow), increased urinary space with features of degeneration vacuolisation (red arrow) in wall of PCT (blue arrow) (H/E X ??

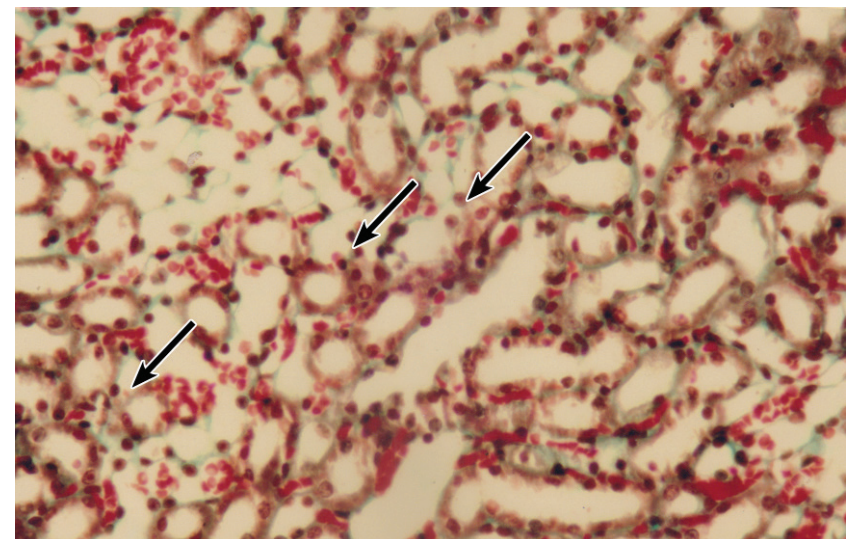

Fig. 3: Microphotograph of a section of kidney of experimental animal showing dilated tubules (Masson's trichrom stain; X 400)

\section{DISCUSSION}

Emerging evidence suggest that MSG had been implicated as toxic to various organs including kidneys.,13 Different mechanism has been postulated for renal damage due to $\mathrm{MSG} .{ }^{9}$ Obesity and leastless behaviour though not related to renal toxicity were constant findings. Others have also noted such behavioral changes. ${ }^{14}$ The mice is an usual experimental animal and neonatal mice had been used because they have not yet developed blood brain barrier..$^{14,15}$

The dose schedule used was similar to some other workers, ${ }^{10}$ but they have used rats as an experimental animal. In the present study gross observation showed initial weight gain and larger intake of food with subsequent loss of interest in food and decreased weight in experimental group (Fig. 4 \& 5). We have not found any comparable literature. Loss of interest in food intake was possibly due to neuropathic changes as suggested by other researcher. ${ }^{16-17}$ Our finding of smaller kidney (Fig. 6 and 7) has been supported by others. ${ }^{8,14}$ We had not found any interstitial fibrosis, though literature is available referring to interstitial fibrosis of renal parenchyma. In the present study we found an 


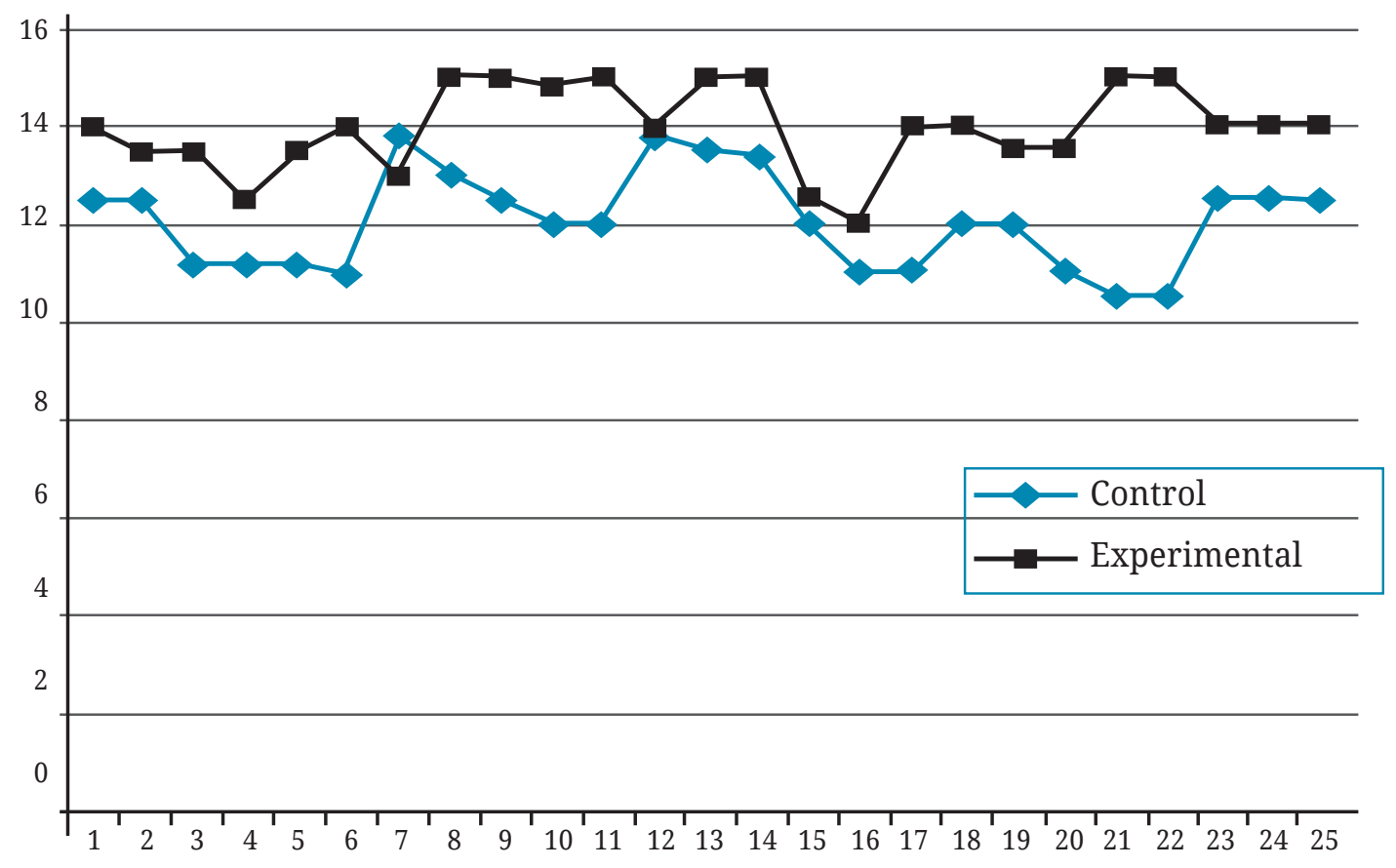

Fig. 4: Showing difference in weight of control and experimental mice on $28^{\text {th }}$ day. (Comparision of weight of control and experimental mice on $28^{\text {th }}$ day)

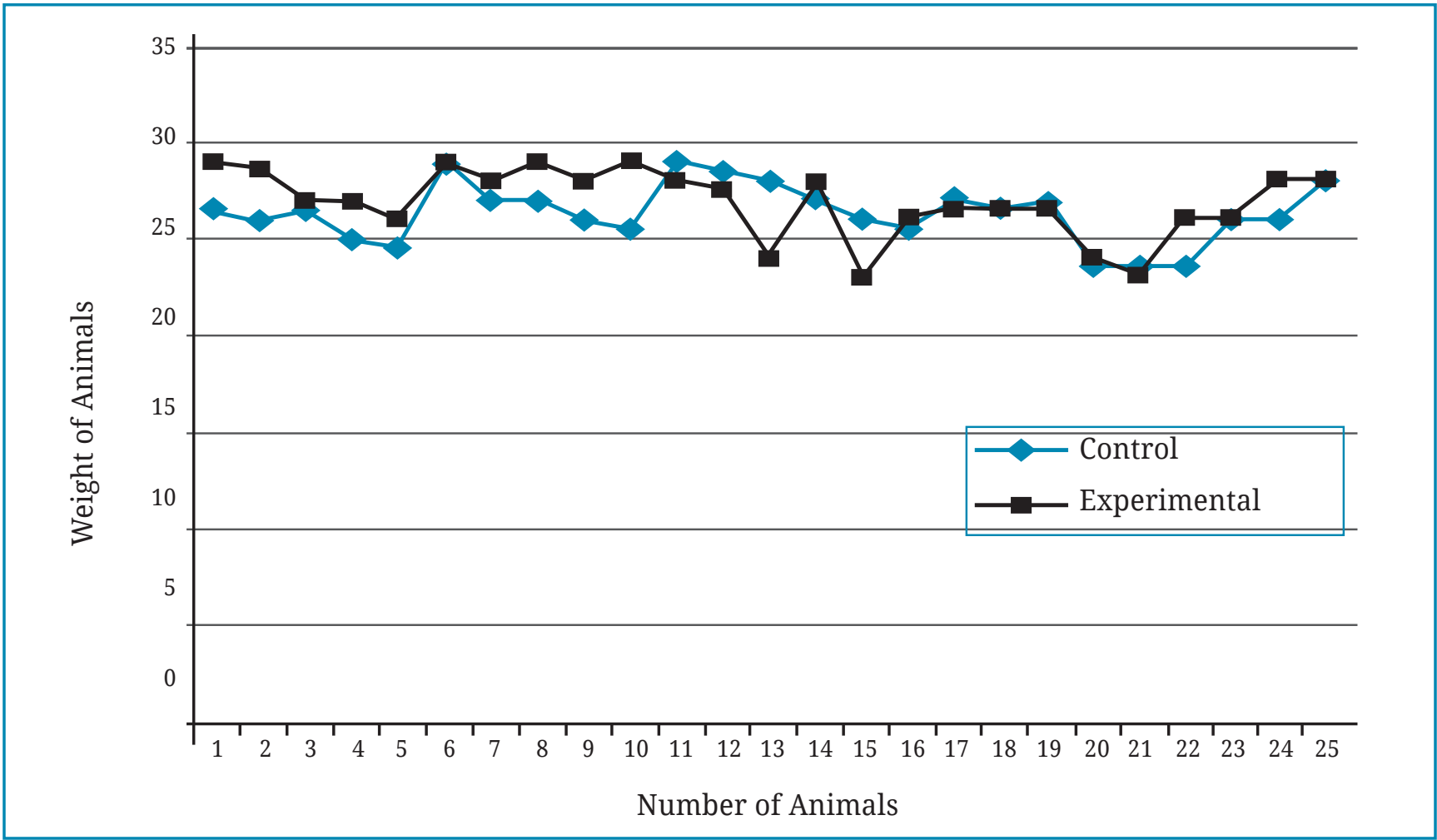

Fig. 5: Showing difference in weight of control and experimental mice on $75^{\text {th }}$ day. Comparision of Weight of Control and Experimental Mice on $75^{\text {th }}$ day

increased urinary space in experiemental group not reported in any other literature. Workers have referred increased cellularity of glomerulus, ${ }^{2}$ which was contrary to our observations. It seems the number of cells of glomeruli are less; possibly due to vacuolation of interstitial space leading to increased glomerular size. We have not found any infiltration of inflammatory cells as reported. ${ }^{9}$ Hence it can be commented that histological changes were due to toxic effects but not due to inflammation. We have found patchy dilatation of renal tubules of both PCT \& DCT. (Fig. 3) Others have found degeneration 


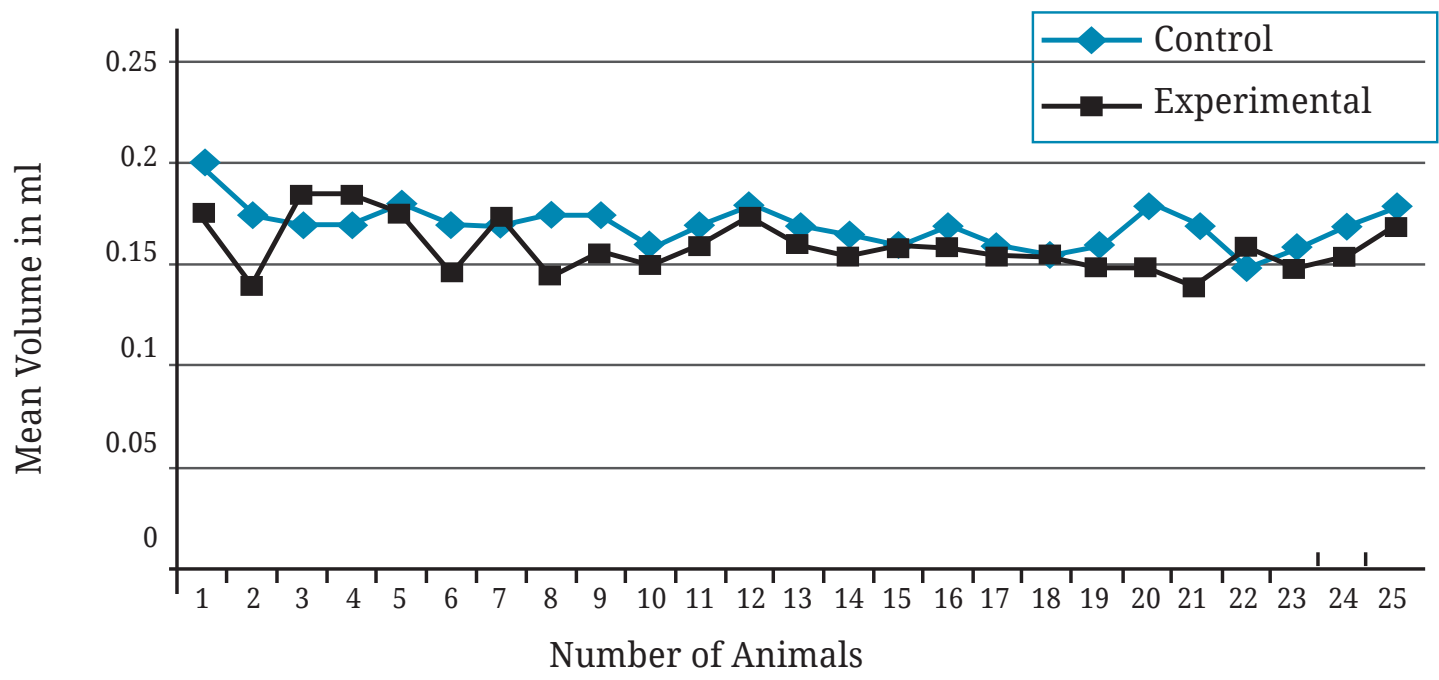

Fig. 6: Comparison of Volume of Kidney of control and Experimental Mice on $28^{\text {th }}$ day.

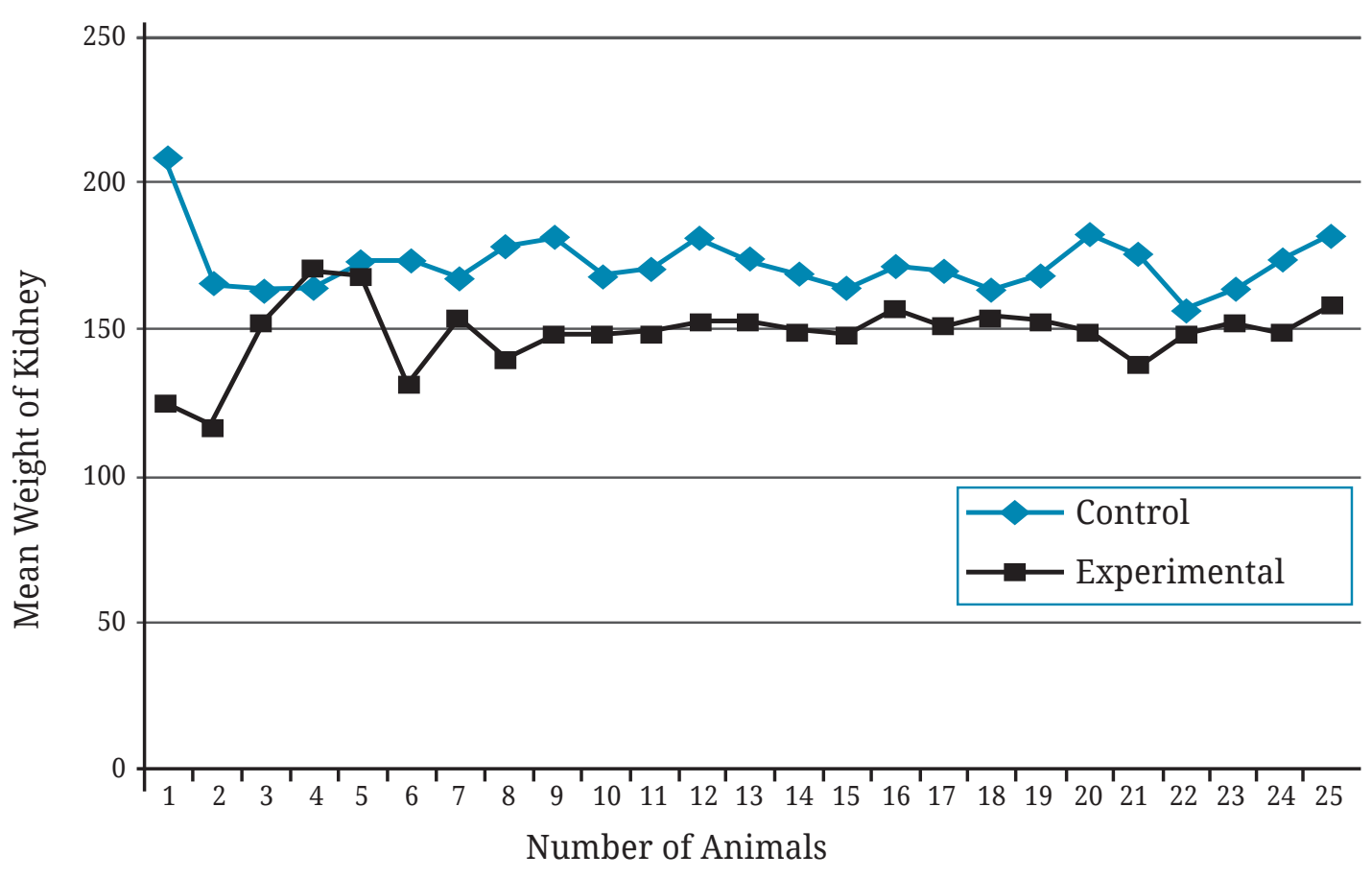

Fig. 7: Comparison of Weight of Kidney of control and Experimental Mice on $75^{\text {th }}$ day.

of cells of tubules which might have caused the dilated appearance of tubules. Some other workers ${ }^{9}$ have reported interstitial fibrosis and in a review suggested an increased hydronephrotic changes in MSG treated rats. We could not comment on oedema of tubular cells as suggested. ${ }^{18}$ In the present study the dose schedule was similar to daily intake of MSG through food in adult human. Difficult to explain these distinct findings among these MSG treated animals but individual factors and diet could have played a role. Sharma ${ }^{9}$ also commented on dose and duration of MSG exposure are vital factors to nephrotoxic effects. As such processes of direct and indirect disturbances of renal cell energy metabolism will result in cell injury and acute renal insufficiency.
In conclusion, the result of this case control study suggested that following prenatal exposure to MSG, a long term damaging effect of MSG on kidneys. The effect of the drug seem to be due to oxidative stress and decrease elimination of free radicals in MSG treated animals. It cannot be predicted what will be the effect of MSG in human kidney. Since renal structure and function in mice and human are similar, hence same results are expected in human too, though higher dose may be necessary. Finally it is recommended that MSG be considered as potentially toxic substance for kidneys of mammalian tissue and hence its long time use should be avoided. 


\begin{tabular}{|lccc|cccc|}
\hline \multicolumn{7}{c|}{ Table 3: Growth Records of control animal } \\
Sr. & Sex & $\begin{array}{c}\text { Wt (gm) } \\
\text { on day 28 }\end{array}$ & $\begin{array}{c}\text { Wt (gm) } \\
\text { on day 75 }\end{array}$ & $\begin{array}{l}\text { Sr. } \\
\text { No. }\end{array}$ & Sex & $\begin{array}{c}\text { Wt (gm) } \\
\text { on day 28 }\end{array}$ & $\begin{array}{c}\text { Wt (gm) } \\
\text { on day } 75\end{array}$ \\
1 & M & 12.5 & 26.5 & 14 & M & 13.4 & 27 \\
2 & M & 12.5 & 26 & 15 & F & 12 & 26 \\
3 & F & 11.2 & 26.5 & 16 & M & 11 & 25.5 \\
4 & F & 11.2 & 25 & 17 & M & 11 & 27 \\
5 & F & 11.2 & 24.5 & 18 & M & 12 & 26.5 \\
6 & M & 11 & 29 & 19 & M & 12 & 26.8 \\
7 & M & 13.8 & 27 & 20 & F & 11 & 23.5 \\
8 & M & 13 & 27 & 21 & F & 10.5 & 23.5 \\
9 & M & 12.5 & 26 & 22 & F & 10.5 & 26 \\
10 & F & 12 & 25.5 & 23 & F & 12.5 & 26 \\
11 & M & 12 & 29 & 24 & F & 12.5 & 28 \\
12 & M & 13.8 & 28.5 & 25 & M & 12.4 & \\
13 & M & 13.5 & 28 & & & & B \\
\hline
\end{tabular}

\section{Table 4: Growth records of experimental animals}

\begin{tabular}{lccc|cccc|} 
Sr. & Sex & $\begin{array}{c}\text { Wt (gm) } \\
\text { on day 28 }\end{array}$ & $\begin{array}{c}\text { Wt (gm) } \\
\text { on day 75 }\end{array}$ & $\begin{array}{c}\text { Sr. } \\
\text { No. }\end{array}$ & Sex & $\begin{array}{c}\text { Wt (gm) } \\
\text { on day 28 }\end{array}$ & $\begin{array}{c}\text { Wt (gm) } \\
\text { on day 75 }\end{array}$ \\
1 & M & 14 & 29 & 14 & M & 15 & 28 \\
2 & M & 13.5 & 28.7 & 15 & F & 12.5 & 23 \\
3 & M & 13.5 & 27 & 16 & M & 12 & 26 \\
4 & M & 12.5 & 27 & 17 & F & 14 & 26.5 \\
5 & M & 13.5 & 26.1 & 18 & F & 14 & 26.5 \\
6 & M & 14 & 29 & 19 & F & 13.5 & 26.5 \\
7 & M & 13 & 28 & 20 & F & 13.5 & 23 \\
8 & M & 15 & 29 & 21 & F & 15 & 26 \\
9 & M & 15 & 28 & 22 & F & 15 & 26 \\
10 & M & 14.8 & 29 & 23 & F & 14 & 28 \\
11 & M & 15 & 28 & 24 & M & 14 & 28 \\
12 & M & 14 & 27.5 & 25 & M & 14 & \\
13 & F & 15 & 24 & & & & \\
\hline
\end{tabular}

\section{Table 5 : Difference body weight (b.w.) of two group of animals}

Mean weight in gm (control)
Mean weight in gm (experimental)
Difference of weight

p value

\begin{tabular}{lcccc} 
Day 28 & 13.97 & 12.04 & 1.93 & $<0.05$ \\
Day 75 & 26.870 & 26.870 & 0.398 & $>0.05$ \\
\hline
\end{tabular}




\begin{tabular}{|c|c|c|c|c|c|c|c|c|c|c|c|c|c|}
\hline \multirow{2}{*}{$\begin{array}{l}\text { Sr } \\
\text { No }\end{array}$} & \multicolumn{3}{|c|}{$\begin{array}{l}\text { Wt of kidney } \\
\text { (mg) }\end{array}$} & \multicolumn{3}{|c|}{$\begin{array}{l}\text { Volume of kidney } \\
\text { (ml) }\end{array}$} & \multirow[t]{2}{*}{$\begin{array}{l}\text { Sr } \\
\text { No }\end{array}$} & \multicolumn{3}{|c|}{$\begin{array}{l}\text { Wt of kidney } \\
\text { (mg) }\end{array}$} & \multicolumn{3}{|c|}{$\begin{array}{l}\text { Volume of kidney } \\
\text { (ml) }\end{array}$} \\
\hline & $\mathbf{R t}$ & $\mathbf{L t}$ & Mean & $\mathbf{R t}$ & $\mathbf{L t}$ & Mean & & $\mathbf{R t}$ & $\mathbf{L t}$ & Mean & $\mathbf{R t}$ & Lt & Mean \\
\hline 1 & 220 & 195 & 207.5 & 0.2 & 0.2 & 0.20 & 14 & 165 & 170 & 167.5 & 0.16 & 0.17 & 0.165 \\
\hline 2 & 172 & 159 & 165.5 & 0.18 & 0.17 & 0.175 & 15 & 159 & 167 & 163 & 0.16 & 0.16 & 0.16 \\
\hline 3 & 165 & 162 & 163.5 & 0.17 & 0.17 & 0.17 & 16 & 185 & 156 & 170.5 & 0.18 & 0.16 & 0.17 \\
\hline 4 & 169 & 159 & 164 & 0.17 & 0.17 & 0.17 & 17 & 173 & 165 & 169 & 0.16 & 0.16 & 0.16 \\
\hline 5 & 163 & 182 & 172.5 & 0.17 & 0.19 & 0.18 & 18 & 167 & 159 & 163 & 0.16 & 0.15 & 0.155 \\
\hline 6 & 174 & 172 & 173 & 0.17 & 0.17 & 0.17 & 19 & 173 & 162 & 167.5 & 0.16 & 0.16 & 0.16 \\
\hline 7 & 167 & 167 & 167 & 0.17 & 0.17 & 0.17 & 20 & 170 & 192 & 181 & 0.17 & 0.19 & 0.18 \\
\hline 8 & 183 & 172 & 177.5 & 0.18 & 0.17 & 0.175 & 21 & 185 & 165 & 175 & 0.18 & 0.16 & 0.17 \\
\hline 9 & 170 & 191 & 180.5 & 0.16 & 0.19 & 0.175 & 22 & 158 & 153 & 155.5 & 0.15 & 0.15 & 0.15 \\
\hline 10 & 176 & 159 & 167.5 & 0.17 & 0.15 & 0.16 & 23 & 169 & 156 & 162.5 & 0.17 & 0.15 & 0.16 \\
\hline 11 & 173 & 167 & 170 & 0.17 & 0.17 & 0.17 & 24 & 174 & 172 & 173 & 0.17 & 0.17 & 0.17 \\
\hline 12 & 179 & 183 & 181 & 0.18 & 0.18 & 0.18 & 25 & 179 & 182 & 180.5 & 0.18 & 0.18 & 0.18 \\
\hline 13 & 165 & 181 & 173 & 0.16 & 0.18 & 0.17 & & & & & & & \\
\hline
\end{tabular}

Mean wt of kidney in control mice: $171.62 \mathrm{mg}$, Mean of volume of kidney in control: $0.17 \mathrm{ml}$

\begin{tabular}{|c|c|c|c|c|c|c|c|c|c|c|c|c|c|}
\hline \multirow{2}{*}{$\begin{array}{l}\text { Sr } \\
\text { No }\end{array}$} & \multicolumn{3}{|c|}{$\begin{array}{l}\text { Wt of kidney } \\
\text { (in mg) }\end{array}$} & \multicolumn{3}{|c|}{$\begin{array}{l}\text { Volume of kidney } \\
\text { (in ml) }\end{array}$} & \multirow[t]{2}{*}{$\begin{array}{l}\text { Sr } \\
\text { No }\end{array}$} & \multicolumn{3}{|c|}{$\begin{array}{l}\text { Wt of kidney } \\
\quad \text { (in mg) }\end{array}$} & \multicolumn{3}{|c|}{$\begin{array}{l}\text { Volume of kidney } \\
\quad \text { (in ml) }\end{array}$} \\
\hline & Rt & $\mathrm{Lt}$ & Mean & Rt & $\mathrm{Lt}$ & Mean & & $\mathrm{Rt}$ & $\mathrm{Lt}$ & Mean & $\mathrm{Rt}$ & $\mathrm{Lt}$ & Mean \\
\hline 1 & 123 & 128 & 125.5 & 0.16 & 0.2 & 0.175 & 14 & 157 & 142 & 149.5 & 0.16 & 0.15 & 0.155 \\
\hline 2 & 113 & 121 & 117 & 0.11 & 0.17 & 0.154 & 15 & 134 & 162 & 148 & 0.14 & 0.18 & 0.160 \\
\hline 3 & 156 & 149 & 152.5 & 0.18 & 0.19 & 0.185 & 16 & 154 & 159 & 156.5 & 0.16 & 0.16 & 0.160 \\
\hline 4 & 141 & 200 & 170.5 & 0.16 & 0.21 & 0.185 & 17 & 149 & 153 & 151 & 0.15 & 0.16 & 0.155 \\
\hline 5 & 167 & 170 & 168.5 & 0.17 & 0.18 & 0.175 & 18 & 152 & 156 & 154 & 0.15 & 0.16 & 0.155 \\
\hline 6 & 121 & 139 & 130 & 0.15 & 0.14 & 0.145 & 19 & 157 & 148 & 152.5 & 0.15 & 0.15 & 0.150 \\
\hline 7 & 145 & 162 & 153.5 & 0.17 & 0.18 & 0.175 & 20 & 143 & 154 & 148.5 & 0.15 & 0.15 & 0.150 \\
\hline 8 & 134 & 146 & 140 & 0.14 & 0.15 & 0.145 & 21 & 139 & 136 & 137.5 & 0.14 & 0.14 & 0.140 \\
\hline 9 & 144 & 151 & 147.5 & 0.16 & 0.15 & 0.155 & 22 & 161 & 134 & 147.5 & 0.18 & 0.14 & 0.160 \\
\hline 10 & 154 & 142 & 148 & 0.16 & 0.14 & 0.150 & 23 & 156 & 147 & 151.5 & 0.16 & 0.14 & 0.150 \\
\hline 11 & 152 & 146 & 179 & 0.16 & 0.16 & 0.160 & 24 & 145 & 152 & 148.5 & 0.16 & 0.15 & 0.155 \\
\hline 12 & 149 & 156 & 152.5 & 0.17 & 0.18 & 0.175 & 25 & 165 & 151 & 158 & 0.17 & 0.17 & 0.170 \\
\hline 13 & 146 & 159 & 152.5 & 0.15 & 0.17 & 0.160 & & & & & & & \\
\hline
\end{tabular}




\section{REFERENCES}

1. Xiong JS, Branigam D, Li M. Deciphering the MSG controversy. Int'l J Chin Exp Med 2009; 2: 329-36.

2. Abdallah CG. Jiang L.DE Feyter HM, Fasula M. Krystal JH. Rothman DL. Glutamate metabolism in major depressive disorder. Am I Psychiatr 2014; 171: 1320-7.

3. Solomon U. Gabriel OO, Henry EO, Adrian T0. Anthony TE. Effect of monosodium glutamate on behavioural phenotypes, biomarkers of oxidative stress in brain tissues and liver enzymes in mice. World J Neurosel 2015: 5: 339-49.

4. Araujo TR. Freitas IN, Vettozazzi JF et al. Benefits of L-alanine or L-arginiine supplementation against adiposity and glucose intolerance in monosodium glutamate-induced obesity. Eur J Nutr 2017; 56: 2069-80.

5. Bawaskar HS, Bawaskar PH, Bawaskar PH. Chinese restaurant syndrome. Indian J Crit Care Med 2017; 21: 49-50.

6. Obayashi Y, Nagamura Y. Does monosodiuma glutamatie really causes headache?: A systematic review of human studies. J Headache Pain 2016: 17: 1-7.

7. Mondal M, Sarkar K, Nath PP, Paul G. Monosodium glutamate suppresses the female reproductive function by impairing the functions of ovary and uterus in rat. Environ Toxicol 2017; 33: 198-208.

8. Dong HV, Robbins WA. Ingestion of monosodium glutamate (MSG) in adult male rats reduces sperm count, testosterone, and disrupts testicular histology. Nutrition Bytes 2015; 19: 1-9.

9. Sharma A. Monosodium glutamate-induced oxidative kidney damage and possible mechanisms: A mini-review. J Biomed Sci 2015; 22: 1-6. doi: 93.10.1186/s12929-015-0192-5.

10. Redding TW, Schally AV, Arimura A, Wakabayashi I. Effect of monosodium glutamate on some endocrine functions. Neuroendocrinology 1971; 8: 245-55.
11. Trentini GP, Botticelli A, Botticelli CS. Effect of monosodium glutamate on the endocrine glands and on the reproductive function of the rat. Fertil Steril 1974: 25: 478-82.

12. Chatterjee TK. Handbook of laboratory mice and rats. Chatterjee KK Publisher 1993; $1^{\text {st }} \mathrm{Ed}$, Calcutta 3-8.

13. Diniz YS, Fanandes AA, Compose KE, Mani F, Ribas BO, Novelli E. Toxicity of hypercaloric diet and monosodium glutamate: oxidative stress and metabolic shifting in hepatic tissue: Food Chem Toxicol 2004; 42: 313-9.

14. Hamaoka K, Kusunoki T. Morphological and cell proliferative study on the effects of visceral organs in monosodium L-glutamate-treated obese mice. $J$ Nutr Sci Vitaminol 1986; 32: 395-411.

15. Talasaki Y. Studies on Brain lesions after administration of monosodium L-glutamate to mice. Toxicology 1978; 9: 307-18.

16. Olney JW and HO OI. Brain damage in infant mice following oral intake of glutamate, aspertate or cysteine. Nature 1970; 227: 609-11.

17. Pizzi WJ, Fabzlow DJ. Monosodium glutamate administration to the new born reduces reproductive ability in female and male mice. Science 1977; 196: 452-4.

18. Paul MV, Abhilash N, Varghese M, Alex M, Nait $\mathrm{RH}$. Protective effects of alpha tocopherol against oxidative stress related to nephro toxicity by monosodium glutamate in rats. Toxicol Mech Methods 2012: 22: 625-30. 